\title{
Levers for Change in Educational Development in Canada: Looking Back, Looking Forward
}

COLLECTED ESSAYS

ON LEARNING

2017 CELT Vol X

celt.uwindsor.ca

www.sthe.ca

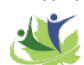

STLHE SAPES

Debra L. Dawson

Western University

DOI: $10.22329 /$ celt.v10ii0.4737

This paper examines levers or drivers that have influenced the direction of educational development in Canada over the last 40 years and also tries to predict what will be the impact of some current levers on changing the work of developers in the next 20 years. Reflecting on those years, it is apparent our work in the 1980s was very focused on the individual and gradually shifted to become more organizational and sector focussed, particularly as the work of developers moved from the periphery to the center of our institutions. The challenge of the next 20 years will be responding to the breadth of areas we are being drawn into in the academy yet, the diversity of our work is one of the strengths of our profession.

$\mathrm{I}^{\mathrm{I}}$

n 2016 I retired from 36 years of working in the field of educational development at Western University. This gave me the opportunity to both reflect on the institutional and national change levers that had influenced the direction the profession has taken in Canada over the decades, and to consider what trends might impact us in the next 20 years. Using Western University as a case study in this essay I will examine models of educational development that have influenced the work we do as educational developers, provide a short history of educational development in Canada, and explore those drivers both past and future that have served to shape our profession.

\section{Models of educational development}

Fraser, Gosling and Sorcinelli (2010) state that there are three primary models of educational development that have framed educational development over the last 35 years. The first model focuses on the individual where the problems being addressed are often at the classroom level. This includes work on course design, review of student feedback, or classroom visits, and is often designed to help instructors develop teaching competence. The second model of educational development concentrates on the institution or organization. This model is more about educational developers facilitating organizational change. Educational development activities are therefore more related to institutional priorities. The final model of educational development emphasizes outcomes at the post-secondary sector level. This model looks at national or provincial concerns with a focus on accountability and the need to provide stronger student outcomes and ensure a high quality of education. As I reviewed each decade of educational development I reflected on which model was dominant at my institution at that time. 


\section{The 60s and 70s}

The 1960s and 70s were a time of firsts in educational development. In 1962 the first educational development unit was established in the United States at the University of Michigan (Lewis, 2010) followed in 1968 by the first centre in Canada for teaching and learning at McGill University (McDonald, 2010). The establishment of this first educational development unit in Canada was rapidly followed with many others being founded including those at the University of Waterloo in 1977 (Knapper, 2010) and the one at Western University in 1979 (J. Purves, personal communication June 12, 2016). Lewis (2010) speculates that the investment in these new centres occurred because of the rapid expansion of enrolment in higher education in the 70s. Knapper (2010) suggests that government willingness to invest in such centres was largely driven by concerns that the quality of education they provided this new cohort of students remained adequate. These new centres often provided audio-visual or technical support to faculty, including supporting computer-aided instruction (Knapper, 1985). Therefore, technology as a driver for change in educational development was evident even in these early days.

\section{The 80s}

My first position in 1980 at the university was being a preceptor, 'a teacher of teachers', who prepared graduate teaching assistants (GTA) to be lab instructors in an introductory psychology course. To learn best practices in GTA development, I first visited McMaster University in Hamilton, where Alan Blizzard and Dale Roy were already established as developers and had written a guide on TA development. Nationally the 80 s saw the expansion of educational development programming occurring from St. Mary's University in Nova Scotia to the University of Victoria in British Columbia (Smith, 1991). In addition, there was a definite interest by both educational developers and faculty to form a Canada-wide organization devoted to enhancing teaching and learning in higher education. This interest was particularly evident in Ontario where the first national conference on teaching and learning had been held at Guelph University in 1981 (Knapper, 1985) and the educational development movement had firmly taken hold (Wilcox, 1998). When the fourth national conference occurred at Western University in 1984 the 110 participants became the charter members of the newly formed Society for Teaching and Learning in Higher Education (STLHE), with Christopher Knapper as the organization's first president (Knapper, 1985). I was among those charter members in addition to Chris Knapper (University of Waterloo), Harry Murray (Western University), Dale Roy and Allan Blizzard (McMaster University), Ron Sheese (York University), and Ron Smith (Concordia University).

Similar to many instructional development offices across the country (Smith, 1991), the teaching and learning centre at Western, the Educational Development Office (EDO) had a half-time director and minimal support staff. Smith mentions that to overcome the lack of support provided at the University of Victoria, the University of British Columbia, and Simon Fraser University, the three post-secondary institutions banded together to form the tri-university Instructional Development group. Western's centre was effectively run by a campuswide committee that did much of the work of the Center, such as organizing an annual conference on teaching and learning and approving book purchases (J. Purves, personal communication September 10, 2015). As in many centres, the sessions presented focused on teaching tips (Boice, 1989), with workshops often being taught by teaching award winners who provided expert advice to participants. Therefore, the work they presented in such sessions was grounded primarily in practice rather than theory. This model of educational development was aimed primarily at individual concerns and was very teacher-focused (Fraser et al. 2010). This was the dominant model for educational development in the 80 s, where developers often spent much of their time working with individual faculty (Boice, 1989). By 1982 I knew working in a teaching and learning centre would be my dream position, yet the small size of most centres made this career goal seem unlikely. 
The establishment of the STLHE in 1984 was a significant step forward in Canadian higher education for educational developers, but concurrently an event was occurring that would dramatically shape the face of post-secondary education in Canada. John Myser, the President of $3 \mathrm{M}$ Canada in the 80 s, became very interested in creating what he hoped would become the "Stanley Cup" of teaching (C. Knapper, personal communication June 21, 2016). As $3 \mathrm{M}$ Canada is located in London, Ontario, he met initially with faculty from Western about such an award and that discussion led to his meeting with members of STLHE (Roy \& Knapper, 2013). In 1985 the new award, the $3 \mathrm{M}$ National Teaching Fellowship (3MNTF), was created in collaboration with the Society with the first members being invited into the fellowship in 1986.

\section{The 90s}

The 1990s marked other significant changes for educational development both, internationally and nationally. In 1993, the International Consortium for Educational Development (ICED) was established with five national teaching and learning networks, including STLHE. ICED also sought to connect with emerging networks to support the development of educational development worldwide (Mason O'Connor, 2016). Today ICED has 24 member organizations (Mason O’Connor, 2016). In 1996 ICED launched the International Journal of Academic Development (IJAD) providing a forum for research on educational development to be shared globally. It has now published 50 issues including 410 articles (Baume, 2016).

Nationally, as recommended by Smith (1991) and reinforced by the AUCC task force on the "Report on the commission of inquiry on Canadian education" (Segal, 1992), we saw the establishment of student evaluations of teaching and teaching dossiers at many universities as key components of evaluating teaching competence for promotion and tenure. At Western University this lead to additional funding for the Educational Development Office as its work became more central to the prime mission of the university.

During this period STLHE began to publish materials that were groundbreaking nationally, such as the "Ethical Principles in College and University Teaching" that was authored in 1996 by five 3MNTF faculty members from Western University: Harry Murray, Madeline Lennon, Eileen Gillese, Paul Mercer, and Marilyn Robinson. This document was endorsed by many other 3MNTF such as Arshad Ahmad, Colin Baird, Guy Allen, Bev and Norman Cameron, Allan Gedalof, Gary Poole, Pat Rogers, Peter Rosati, and Wayne Weston. Another tremendously influential piece published in the STLHE newsletter in 1997 was "Making Teaching Count in Canadian Higher Education: Developing a National Agenda” by Ron Smith. This article became a call to arms for educational developers as it demanded that we view teaching from a scholarly perspective, and proposed that faculty should be required to develop teaching competence in addition to research competence to do their work properly as academics. It was during this very exciting period in educational development that my role moved from an academic department at Western to the central educational development unit.

The need for making teaching count was nowhere more evident than in Ontario where the Harris government (1995-2002) severely cut funding to universities (Jones, 2004). As a result, universities started creating large classes as a response to this funding crisis. In the $90 \mathrm{~s}$ at both Western and the University of Toronto, there were suddenly classes that had enrollments of over 1000 students - a size previously thought to be unteachable. One response to this concern was the 1998 publication of Allan Gedalofs "Teaching Large Classes", the first of STLHE's Green Guide series. The new technologies made connecting with many students far more viable with most universities adopting a learning management system for the first time. However, concern about the quality of education provided in these mega classes led to an expansion of funding to educational development units to provide supports to faculty to facilitate large class teaching. 
Therefore during the 90s, the framework for educational development had moved beyond the focus on the individual faculty member to emphasizing more closely institutional needs. As Fraser et al. (2010) noted, concentrating on individual concerns does not often address the systemic issues that may be hindering the improvement of teaching and learning at the institutional level. Government attention to the quality of education meant that universities, especially the research intensive universities (the G10 or what is now the U15), started to measure and post on their websites quality indicators, such as student retention rates and student time to completion of their undergraduate degrees, to allow for comparative analysis and benchmarking (Davenport, 2005). Furthermore in the 90s Canadian educational developers became more involved with contributing to university strategic plans and teaching and learning centres became embedded in a variety of task force initiatives (The University of Western Ontario, 2001; University of British Columbia, 2000). Thus, educational development was now much more closely aligned with institutional needs and priorities as defined by senior administration and impacted the strategic directions they adopted. We had started to move from the periphery to the center of organizational change within the institution (Dawson, Mighty, \& Britnell, 2010).

\section{The 2000s}

Drivers that were dramatically transforming the landscape of higher education in the 2000s included the need for faculty renewal with many universities having their largest hiring of new faculty since the 1970 s, increased interest in internationalization of university curricula and increasing international student presence on Canadian campuses (Canadian Bureau for International Education, 2015), and within Ontario, the double cohort on campus and the strong call for graduate student expansion (Williams, 2005). All of these drivers led to changes in the work of developers on our campuses and, in many cases, increased funding for educational development centres. At Western University the number of fulltime staff increased from less than 2 in the 90s to 11 in the 2000s. This expansion of the mandate of the centres-from remediation centres to drivers of change shifted the work of our centres throughout the country (Dawson, Mighty, \& Britnell, 2010). For example at Western, the work with graduate students moved from simply providing GTA training to supporting these students throughout their graduate years, to ensure the timely completion of their degrees, and to assist them with successfully applying for future employment. With the sudden expansion of new faculty, a mentor program was created to help ensure retention and for international graduate students, a full-time language instructor was hired to facilitate the international students' transition to the Canadian classroom.

The focus on technology also changed the work of developers with Western University creating a new centre, The Teaching Support Centre, which was seen as a one-stop-shop for enhancing teaching and learning on campus and included both instructional technology services and the libraries in the new centre. Physical movement of the centre from the administration building to one of the main libraries also demonstrated how the centre's status had shifted on campus.

This growth in educational development activities at Western was echoed throughout the country. In the 1990s the Instructional Development Officers (as the leaders of educational development units were called) used to have an annual meeting in Vancouver where they could all sit around a table in a large room together. By the early 2000s, this group had grown and it was evident that educational development as a unique profession had come of age. 2003 saw the creation of the Educational Development Caucus as a unique constituency within STLHE. This group has now had four chairs and currently has a membership of approximately 300 (personal communication S. Chu February 20, 2016).

Within Ontario, another driver that was strongly influencing higher education at this time was the Rae (2005) report and its recommendations (Ontario: A leader in learning). In particular, the recommendation for the formation of the Higher 
Education Quality Council of Ontario (HEQCO) changed the emphasis at universities from their strong research mandate to also focusing on teaching. Educational developers within Ontario for the first time had the opportunity to apply for funding specifically for projects related to the scholarship of teaching and learning and the scholarship of educational development. The list of funded projects from HEQCO has been truly impressive over the past 10 years (see http://www.heqco.ca/en-ca/Research/R esearch\%20Publications/Pages/Home.aspx).

HEQCO's emphasis on quality assurance led universities to support educational development initiatives. Sector-wide there was now a much stronger focus on quality assurance of the programs offered by post-secondary institutions. In Ontario, there was the development of a more regimented program review process mandated by the provincial government. Our work as developers had now moved into the third realm proposed by Fraser et al. (2010) in that it now stressed outcomes at the post-secondary sector. We were working at a level previously unknown to most developers.

Nationally, another disrupter for higher education at this time was the teaching of the first massive open online course (MOOC) by George Siemens and Stephen Downes of the University of Manitoba in 2008. This course which had an enrollment of 2200, demonstrated the impact technology could have on changing the nature of higher education, not just in Canada, but worldwide (Dennis, 2012).

\section{The 2010s}

The 2010s illustrated it was not just the use of technology in MOOCs where technology was rapidly having an impact on higher education and in turn the work of educational developers. As the Horizon report of 2015 stated new technologies had been developed that allowed the reach of education to go significantly beyond the classroom. Universities were starting to investigate makerspaces that would facilitate the design, and more importantly, the creation of objects with 3D printers (Johnson, Adams Becker, Estrada \& Freeman, 2015). The use of wearable technology, such as smartwatches, smart clothing, and Google glasses, could connect students to the Internet without a computer while adaptable learning technologies would adjust to their individual needs. Finally, the Horizon report suggested the Internet of Things would connect the Internet to real items in the world. These types of technologies, they suggest, would be a game changer in higher education. However, the inclusion of the new technologies to enhance teaching and learning broadened the scope of what we must be doing as educational developers in terms of programs provided and support for faculty.

Another change that has occurred in the 2010s is that centres' support for internationalization moved beyond assisting international faculty and graduate students with teaching in the Canadian classroom and facilitating the development of international curriculum development, to also connecting more widely with educational developers and faculty worldwide (Mason O'Connor, 2016). Western University has hosted faculty from the University of Dar es Salaam, the Aga Khan University, and the University of the West Indies at a number of workshops. Other universities have formed similar partnerships, with Queen's University frequently working with faculty and developers from Japan and the University of Windsor hosting visiting fellows from China, Australia, New Zealand, Nigeria, Jamaica, England, and the United States (see http://www1.uwindsor.ca/ctl/visiting-fellows). EDC has formed a close relationship with the Scottish Higher Education Developers (SHED) working together to develop a webinar series on educational development. More recently, board members from STLHE were invited to give several educational development workshops and a symposium on the scholarship of teaching and learning at Teikyo University in Japan (J. McDonald, personal communication June 21, 2016). Again, this broadened the global reach of educational development.

Although the International Society for the Scholarship of the Teaching and Learning was founded in 2004, the increasing importance of SoTL in Canada was established in the late 2000s, with the emergence of two new peer-reviewed journals on the 
scholarship of teaching (SoTL) with STLHE launching the annual Collected Essays on Learning and Teaching in 2008 followed two years later by the Canadian Journal for the Scholarship of Teaching and Learning. More recently we have seen SoTL Canada becoming a formal constituency of STLHE. The work of educational developers now has broadened with many centres such as the ones at McMaster University, the University of Calgary, and the University of British Columbia all devoting a significant amount of their time and budget to fostering an environment that strengthens SoTL on their campuses (Simmons \& Poole, 2016). Randall, Heaslip, and Morrison (2013) found that SoTL is thriving within British Columbia's higher education system as indicated by the many institutions involved in SoTL conferences, research, and the publication of another Canadian online journal: Transformative Dialogues. Educational development work has shifted to not just incorporating an evidence-based approach to practice but to supporting the creation of that evidence. The complexity of the lives of educational developers cannot be understated.

Another prominent driver for changing the work of educational developers across the sector Canada-wide was the release in 2015 of the Truth and Reconciliation Report and its calls to action to transform education at all levels. Many universities across Canada have developed Indigenous strategic plans specifically to address this report (see for example the University of British Columbia's strategic plan http://strategicplan.ubc.ca/theplan/aboriginal-engagement/). It is too early to see what the impact of the report will be but within the EDC there is tremendous interest in supporting this vital initiative and an Action Group has been established to determine how we as educational developers might support the report's recommendations. This will be a challenging task for developers as only $3 \%$ of the university population are currently Indigenous (Association of Universities and Colleges of Canada, 2011). Plus as Mighty, Ouellett, and Stanley (2010) argue there have been many missing voices in the field of educational development and this is certainly true of Indigenous voices in educational development in Canada.
Finally, another major trend in the 2010s has been the shift towards students becoming collaborators in teaching and learning research projects rather than being seen as the research subjects of such inquiries. A recent 2016 issue of the International Journal for Academic Development highlighted such initiatives. McMaster University developed a student scholars program in 2013 and now has approximately 50 students per year working actively on projects associated with their centre (see http://mi.mcmaster.ca/student-partners-program/).

This supports Bovill and Felton's (2016) contention that educational developers have a unique role to play in facilitating the development and sustainability of such student-faculty relationships.

These, then, are some of the trends and drivers that I believe have shaped educational development until this point. Our work has shifted from a focus on the individual in the 1960s, 70s, and 80 s to an emphasis on the organization in the 90 s to today's concentration on the entire post-secondary sector. What, then, are new trends or drivers that are likely to influence the work of educational developers in the next 20 years?

\section{Looking forward}

The significant trends or levers I see on the horizon are changing faculty roles, changing student demographics, the scholarship of educational development, and, as always, technological innovation. Let me briefly elaborate on each of these.

Shifting faculty roles includes the emergence of teaching-stream faculty and the increase in sessional appointments (Austin \& Sorcinelli, 2013). Teaching-stream faculty can now be found at many universities across Canada such as the University of Toronto, Simon Fraser University, and the University of British Columbia. As we move away from the traditional 40, 40, 20 faculty role (research, teaching, and service) this may create a unique opportunity for developers to provide programming to instructors whose attentions are not divided between teaching and their disciplinary research. However, many of these teaching-stream faculty are 
participating in the scholarship of teaching and learning so our role is shifting to facilitate their development of this new research area. Concurrent to the growth of teaching-stream faculty has been the rise of sessional faculty within our institutions (MacDonald, 2013). This will require us to re-think traditional educational development models of programming to accommodate their diverse needs, such as instructors being on campus only in the evenings or weekends or never being on campus at all due to their teaching being entirely online. More of our educational development programming will need to be online, and we will need to find a way to create as good a sense of community in this new environment as what we currently produce in our face-to-face settings (Kanuka \& Rouke, 2013). Also, in general, new faculty feel more stretched than ever about the need to increase their research productivity while maintaining quality teaching (Sorcinelli, Austin, Eddy \& Beach, 2006). All of these changes in faculty work life will require educational developers to become more nimble in response to these diverse needs.

Not only are our faculty changing but so are our students. The Association of Universities and Colleges of Canada (AUCC, 2011) reported that $24 \%$ of our students are now working part time with many working full time or close to full time. The report suggests that increases in government funding to higher education has come about largely in recent years as a result of an increase in the number of students, but this growth in student numbers is not sustainable. If we wish to continue to grow we need to diversify our traditional student base to include non-traditional students, such as mature and parttime students, and then improve the quality of education to increase the retention of these students.

Students within our universities have a greater diversity of backgrounds than previous generations (Austin \& Sorcinelli, 2013) and at some universities, the percentage of international students is now 30\% (AUCC, 2011). In Canada, if we are to be responsive to the needs of Indigenous students then we will need to integrate the principles suggested by Universities Canada in 2015 and help support the Indigenization of curricula. Knapper (2016) suggests this increasingly diverse student body poses a challenge to developers who must respond to these changing demographics yet often still do not have a significantly strong voice within the university to influence how the senior administration will respond to these pressing needs. However, our centres are often places where diverse members of the academic communities meet and we need to be part of a discussion that helps bring Indigenous and more inclusive pedagogies into our post-secondary classrooms (Dimitrov \& Haque, 2016).

The scholarship of educational development (SoED) is also coming into its own as a distinct area of study (Geertsema, 2016). Much as fostering SoTL within the academy was a major driver for educational developers starting in the 2000s, it is apparent now that the scholarship of educational development has taken off as the primary research of many developers. Geertsema comments that not only are we interested in examining critical questions about teaching and learning in our classrooms, we are now taking a far more theoretical and research-based approach to our own practice in order to provide evidence that the outcomes of educational development activities are being achieved. The emergence of this new form of scholarship seems critical to our identity formation as educational developers. As McDonald (2010) found most of us migrate to the profession of educational development from disciplines not directly related to higher education so learning how to perform SoED remains a challenge. Yet, I believe that this is essential if we are to continue to grow as a profession within higher education. We must take as rigorous an approach to our own practice as our faculty colleagues do to their discipline-specific research.

Finally, one lever for change that remains from the 80s is technological innovation. Now more than ever it is an extremely powerful factor affecting both how we teach and how students learn (Austin $\&$ Sorcinelli, 2013). Therefore, it is not surprising that many centres for teaching and learning have merged with centres for technology (Lewis, 2010). However, much as these new technologies offer many possibilities to transform how students learn, they also present many challenges for both developers and the faculty with which they work, as the types of innovations are ever changing (Austin \& Sorcinelli, 2013). 
Johnson et al. (2015) purport that more opportunities need to be available for faculty, and I would suggest educational developers experiment with innovative technologies. More importantly, they state that within our universities research is still valued over teaching. The lack of recognition for exemplary and innovative teaching within the postsecondary sector is what they call "a wicked challenge" (p. 1). A problem they say is hard to define and even harder to solve. This wicked challenge was identified many years ago in Canada in the 1991 Smith report that discussed how undervalued teaching was in higher education. Recent work by Kustra et al. (2014) has sought to find ways to measure and enhance the teaching culture found at many Canadian universities. Without a reward structure for the time and energy faculty must invest in learning about new technologies it will remain difficult for us to convince faculty to fully integrate and keep up-to-date on the use of technology in the classroom. This is a major challenge currently for educational developers.

\section{Conclusion}

Sorcinelli \& Austin (2010) state "educational development is a key strategic lever for ensuring institutional quality and supporting institutional change around the globe" (p. 25), therefore developers need to be aware of and responsive to educational change drivers such as quality assurance policies or technology innovations. Many educational developers have stressed in the last few years the need for us to become change leaders both on our campus and throughout the higher education sector if we are to be successful in our role on campus (Austin \& Sorcinelli, 2013; Baume, 2016; Taylor, 2005). Much as these changes add to the complexity of our roles on campus, they are also what makes educational development such a fascinating profession requiring individuals who thrive on new challenges and are truly dedicated to lifelong learning. Fraser et al. (2010) identify the prevalence on our campuses of the three models of educational development at the individual, organizational, and sector level all leading to our increasing influence. If we are to continue to be seen as essential to our institutions we must as Knapper (2016) indicates see "our changing role as inevitable [if] we are to play a part in the transformation of teaching to meet the new demands and realities of the twenty-first century university"(p. 114). I am honoured to have spent my working life in such an environment and am excited to see how educational developers will meet the demands of the next 20 years.

\section{References}

Association of Universities and Colleges of Canada (2011). Trends in Higher Education. Ottawa, ON: AUCC. VIEW ITEM

Austin, A. E., \& Sorcinelli, M. D. (2013). The future of faculty development: Where are we going? New Directions for Teaching and Learning, 2013(133), 85-97. VIEW ITEM

David Baume (2016) Analysing IJAD, and some pointers to futures for academic development (and for IJAD). International Journal for Academic Development, 21(2), 96104. VIEW ITEM

Bovill, C., \& Felton, P. (2016). Cultivating studentstaff partnerships through research and practice. International Journal for Academic Development, 21(1), 1-3. VIEW ITEM

Boice, R. (1989). Psychologists as faculty developers. Professional Psychology: Research and Practice, 20(2), 97-104. VIEW ITEM

Canadian Bureau for International Education (2015). A world of learning: Canada's potential and performance in International Education. VIEW ITEM

Davenport, P. (2005). Performance and activity indicators: Annual report to the Board of 
Governors. London, ON: The University of Western Ontario. VIEW ITEM

Dawson, D., Mighty, J., \& Britnell, J. (2010). Moving from the periphery to the center of the academy: Faculty developers as leaders of change. New Directions for Teaching and Learning, 2010(122), 69-78. VIEW ITEM

Dennis, M. (2012). The impact of MOOCs on higher education. College and University, 88(2), 24-30. VIEW ITEM

Dimitrov, N. \& Haque, A. (2016). Intercultural teaching competence in the disciplines: Teaching strategies for intercultural learning. In G. M. G. Perez \& C. Rojas-Primus (Eds.), Promoting Intercultural Communication Competencies in Higher Education (pp. 89119). Hershey PA: ICI Global.

Fraser, K., Gosling, D., \& Sorcinelli, M. D. (2010). Conceptualizing evolving models of educational development. New Directions for Teaching and Learning, 2010(122), 49-58. VIEW ITEM

Gedalof, A. J. (1998). Teaching large classes. Halifax, NS: Society for Teaching and Learning in Higher Education.

Geertsema, J. (2016). Academic development, SoTL and educational research. International Journal for Academic Development, 21(2), 122-134. VIEW ITEM

Johnson, L., Adams Becker, S., Estrada, V., and Freeman, A. (2015). NMC Horizon Report: 2015 Higher Education Edition. Austin, TX: The New Media Consortium. VIEW ITEM

Jones, G. A. (2004). Ontario higher education reform, 1995-2003: From modest modifications to policy reform. The Canadian Journal of Higher Education, 34(3), 39. VIEW ITEM
Kanuka, H., \& Rourke, L. (2013). Using blended learning strategies to address teaching development needs: How does Canada compare? The Canadian Journal of Higher Education, 43(3), 19-35. VIEW ITEM

Knapper, C. (2016). Does educational development matter? International Journal for Academic Development, 21(2), 105-115. VIEW ITEM

Knapper, C. (2010). Plus ça change ... educational development past and future. New Directions for Teaching and Learning, 2010(122), 1-5. VIEW ITEM

Knapper, C. (1985). From the editor: Our first newsletter. Teaching and Learning in Higher Education, 1, 1.

Kustra, E., Doci, F., Meadows, K., Dawson, D., Diske Honzel, C., Goff, L., Wolf, P., Ellis, D. Grosse, J. Borins, P. \& Hughes, S. (2014). Teaching culture indicators: Enhancing quality teaching. Toronto, ON: Ministry of Training, Colleges and Universities. VIEW ITEM

Lewis, K. G. (2010). Pathways toward improving teaching and learning in higher education: International context and background. New Directions for Teaching and Learning, 2010(122), 13-23. VIEW ITEM

MacDonald, M. (2013). Sessionals up close. University Affairs, 54(2), 20-19. VIEW ITEM

Mason O'Connor, K. (2016). Promoting academic development: a history of the International Consortium for Educational Development (ICED). International Journal for Academic Development, 21(2), 116-121. VIEW ITEM

McDonald, J. (2010). Charting pathways into the field of educational development. New Directions for Teaching and Learning, 2010(122), 37-45. VIEW ITEM 
Mighty, J., Ouellett, M. L., \& Stanley, C. A. (2010). Unheard voices among faculty developers. New Directions for Teaching and Learning, 2010(122), 103-112. VIEW ITEM

Murray, H., Gillese, E., Lennon, M., Mercer, P., \& Robinson, M. (1996). Ethical principles for college and university teaching. New Directions for Teaching and Learning, 1996(66), 57-63. VIEW ITEM

Randall, N., Heaslip, P., \& Morrison, D. (2013). Campus-based educational development \& professional learning: Dimensions and directions. Vancouver BC: BCcampus. VIEW ITEM

Rae, B. (2005). Ontario a leader in learning: Report and recommendations. Toronto: Ontario Ministry of Colleges and Universities. VIEW ITEM

Roy, D., \& Knapper, C. (2013). Origins of the 3M "The Stanley Cup of Teaching" [video]. Canada: Society for Teaching and Learning in Higher Education. VIEW ITEM

Segal, B. (1992). Report of the AUCC task force on the "Report of the commission of inquiry on Canadian University education. Ottawa, $\mathrm{ON}$ : Association of Universities and Colleges Canada. VIEW ITEM

Simmons, N., \& Poole, G. (2016). The history of SoTL in Canada: Answering calls for action. New Directions for Teaching and Learning, 2016(146), 13-22. VIEW ITEM

Smith, R. (1997, June). Making teaching count in Canadian higher education: Developing a national agenda. Teaching and Learning in Higher Education, Newsletter for the Society for Teaching and Learning in Higher Education (STLHE), 1997(21), 1,3-10.
Smith, S.L. (1991). Report of the Commission of Inquiry on Canadian University Education. Ottawa, Canada: AUCC.

Sorcinelli, M.D., Austin, A.E., Eddy P.L., \& Beach, A.L. (2006). Creating the future of faculty development: learning from the past, understanding the present. Anker Publishing Boston, MA.

Sorcinelli, M. D., \& Austin, A. E. (2010). Educational developers: The multiple structures and influences that support our work. New Directions for Teaching and Learning, 2010(122), 25-36. VIEW ITEM

Taylor, K. L. (2005). Academic development as institutional leadership: An interplay of person, role, strategy, and institution. International Journal for Academic Development, 10(1), 31-46. VIEW ITEM

The University of Western Ontario (2001). Report of the Strategic Planning Task Force, December 2001: Making choices- Western's commitments as a research-intensive university. London, ON: The University of Western Ontario. VIEW ITEM

Universities Canada (2015). Principles on indigenous education. VIEW ITEM

University of British Columbia (2000). Trek 2000: $U B C$ 's vision. Vancouver: UBC.

Wilcox, S. (1998). The role of the educational developer in the improvement of university teaching. The Canadian Journal of Higher Education, 28(1), 77-104. VIEW ITEM

Williams, G. (2005). Doctoral education in Canada 1900-2005. Ottawa, ON: Canadian Association for Graduate Students. VIEW ITEM 


\section{Acknowledgements}

This paper is based on Debra Dawson's keynote address upon being awarded the 2016 Christopher Knapper Lifetime Achievement Award from STLHE. The keynote was a tribute to Dr Knapper's lifetime of work in educational development and his role as an incredible mentor and colleague to Debra and many others in the Educational Development Caucus community.

\section{Biography}

Dr Debra L. Dawson was the Director of the Teaching Support Centre at Western University from 1997 to 2016, the Chair of the Education Developers Caucus from 2012-2016, and currently, is the Director of the Centre for Research on Teaching and Learning in Higher Education at Western University. 


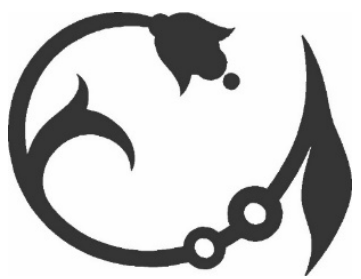

